\title{
Direct-acting antivirals and chronic hepatitis C: towards elimination
}

\author{
Ricardo A. Franco', James W. Galbraith², Edgar T. Overton'1, Michael S. Saag' \\ 'Department of Medicine, Division of Infectious Diseases, University of Alabama at Birmingham, Birmingham, AL 35294, USA. \\ ${ }^{2}$ Department of Emergency Medicine, University of Mississippi Medical Center, Jackson, MS 39216, USA.
}

Correspondence to: Dr. Ricardo A. Franco, Department of Medicine, Division of Infectious Diseases, University of Alabama at Birmingham, 908 20th Street South, CCB 330B, Birmingham, AL 35294, USA. E-mail: rfranco@uabmc.edu

How to cite this article: Franco RA, Galbraith JW, Overton ET, Saag MS. Direct-acting antivirals and chronic hepatitis C: towards elimination. Hepatoma Res 2018;4:74. http://dx.doi.org/10.20517/2394-5079.2018.94

Received: 13 Aug 2018 First Decision: 7 Sep 2018 Revised: 17 Nov 2018 Accepted: 18 Nov 2018 Published: 14 Dec 2018

Science Editor: Guang-Wen Cao Copy Editor: Cui Yu Production Editor: Huang-Liang Wu

\begin{abstract}
Hepatitis $\mathrm{C}$ virus (HCV) is a major cause of liver morbidity and mortality worldwide with increasing disease burden projected for the next several decades. The timely advent of direct-acting antivirals (DAAs) sparked significant public health responses aimed at HCV elimination by 2030. This review will focus on the implications of the DAAs in terms of medical progress, barriers to HCV elimination as a public health threat, and current gaps that will require further innovation. We utilized PubMed searches with the relevant keywords for articles published in the last 5 years, as well as personal collections of relevant publications. DAAs have proven to be safe and effective. DAAs are well suited for nearly all infected patients, and many countries worldwide have taken on initial treatment scale-up strategies. These unprecedented efforts, albeit significant, face extraordinary challenges related to the high infection burden, stigma, and financial constraints. Currently, few countries are progressing towards HCV elimination, as this attainable public health goal requires explicit, adequately resourced, and coordinated public health prioritization at all levels.
\end{abstract}

Keywords: Direct-acting antivirals, hepatitis surveillance, hepatitis $C$ elimination

\section{INTRODUCTION}

Chronic hepatitis $\mathrm{C}$ virus (HCV) is a blood-born viral infection that affects over 71 million people worldwide, representing a major cause of liver morbidity and mortality ${ }^{[1-3]}$. HCV chronically infects hosts as a complex mixture of related variants or "quasispecies", able to genetically evolve and escape host immune responses $^{[4]}$. Paradoxically, HCV-specific cytotoxic T-cell immune responses lead to hepatocyte injury, liver fibrosis progression and complications [cirrhosis and hepatocellular carcinoma (HCC) ${ }^{[5]}$. Although no effec-

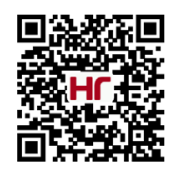


tive vaccine is currently available, HCV infection is amenable to cure if potent antivirals fully and quickly suppress virus replication. Sustained virologic response (SVR), i.e., cure, is achieved following therapy completion in $>95 \%$ of treated individuals ${ }^{[6,7]}$. Direct-acting antivirals (DAAs) have shown superior safety and efficacy compared to interferon-based regimens ( $>95 \%$ vs. $40 \%$ cure rates, respectively), and revolutionized HCV treatment paradigms towards broader access to cure ${ }^{[8]}$. The 69th World Health Assembly endorsed the global health sector strategy to eliminate HCV infection by 2030, which can become a reality with expanded use of DAAs ${ }^{[9]}$. Here, we describe the current prospects of HCV eradication in the DAA era and ongoing challenges to achieve elimination goals.

\section{CLINICAL IMPACT OF DIRECT-ACTING ANTIVIRALS}

In 2012, Lok et al ${ }^{[10]}$ reported successful treatment of patients who were null responders to peg-interferon and ribavirin, infected with genotype $1 \mathrm{a}$ and $1 \mathrm{~b} \mathrm{HCV}$, who received a 24-week course of asunaprevir, a protease inhibitor, and daclatasvir, a non-structural protein 5A inhibitor. This preliminary, proof of concept study demonstrated that SVR (virologic cure) could be achieved by the combination of two DAAs in patients who did not respond to the standard of care at the time. It also signified the culmination of a sequence of major breakthrough discoveries that followed the cloning of HCV for the first time in $1989^{[11]}$. Such progress in basic science allowed, over the ensuing years, for elucidation of key functions of the HCV genome and the virus life cycle; engineering of "sub-genomic" replicons; and development of functional cell-based in vitro systems suitable to screen compound candidates for effective treatment ${ }^{[12,13]}$. Lok's study led the way of an impressive wave of clinical studies, that applied several combinations of DAAs at an extraordinarily fast pace $^{[14]}$. From these clinical studies, we learned that DAAs proved to be safe and effective in addressing unmet needs of key subpopulations, traditionally unreached by interferon-based therapies. State-of-art treatment options were made available for patients with human immunodeficiency virus (HIV) co-infection ${ }^{[15-22]}$, decompensated cirrhosis ${ }^{[23-28]}$, post-liver transplantation ${ }^{[29-33]}$, chronic kidney disease ${ }^{[34,35]}$, renal transplant patients ${ }^{[36-38]}$, and children ${ }^{[39,40]}$. These clinical studies also defined best practices in overcoming HCV resistance. Highly efficacious retreatment strategies could still be utilized for the few patients experiencing DAAfailure and emergence of resistance associated substitutions ${ }^{[41-46]}$.

The field quickly evolved towards the recognition that HCV can be eradicated from most, if not all, infected individuals, expanding the benefits of virus clearance ${ }^{[4]}$. Virologic cure has been shown to universally decrease liver inflammation, reflected by improved aminotransferase levels and reduced rates of liver fibrosis progression. In some patients, achieving SVR also leads to cirrhosis regression and improvement in clinical signs of portal hypertension and end-stage liver disease ${ }^{[48]}$. Numerous studies have demonstrated strong associations between SVR and significant reductions in the risk of HCC, liver-related mortality and liver transplantation $^{[49-51]}$. In addition to these major clinical benefits, cure of HCV infection ameliorates or facilitates management of extra-hepatic manifestations such as cryoglobulinemia, non-Hodgkin's lymphoma, diabetes and porphyria cutanea tarda ${ }^{[52-54]}$. The lower complexity of DAA therapy has made investigators and clinicians challenge the preconceived notion that expeditious HCV treatment would only benefit highly selected patients who exhibited liver fibrosis METAVIR stage 2 at a minimum ${ }^{[55]}$. Well-designed cohort and modeling studies have suggested that early therapy in patients with no significant liver fibrosis have tremendous clinical benefits with SVR ${ }^{[5-58]}$. Similarly, patient reported outcome assessments from pivotal DAA trials have shown improvements in overall health-related quality of life and work productivity following successful HCV therapy ${ }^{[59-61]}$. These findings build on previous studies reporting reductions in fatigue after HCV cure with interferon and ribavirin ${ }^{[62]}$. Taken together, this body of work highlights the extraordinary clinical benefit potential of expanding use of DAAs [Table 1].

In addition, the medical field has clarified the lack of accurate data regarding HCC risk following DAA therapy ${ }^{[63,64]}$. Initially, concerns were raised that abrupt HCV viral load suppression using DAAs could hypothetically abolish the immune system surveillance or "brake" defenses to tumor progression. Further meta- 
Table 1. Benefits of hepatitis $\mathrm{C}$ cure by scaling-up direct-acting antivirals

\begin{tabular}{|c|c|}
\hline Primary prevention & Cirrhosis among patients with chronic infection \\
\hline Clinical & $\begin{array}{l}\text { Decreased liver inflammation } \\
\text { Reduced rates of liver fibrosis progression } \\
\text { Cirrhosis regression } \\
\text { Potential improvement in portal hypertension and ESLD } \\
\text { Improved management of extra-hepatic manifestations } \\
\text { Reductions in insulin resistance } \\
\text { Improved energy, cognition and quality of life measures }\end{array}$ \\
\hline Secondary prevention & $\begin{array}{l}\text { HCC among cirrhotic patients } \\
\text { Liver-related mortality and liver transplantation } \\
\text { Al disorders, PCT, B-cell non-Hodgkin's lymphoma } \\
\text { All-cause mortality }\end{array}$ \\
\hline Public health & $\begin{array}{l}\text { Expanded cure to special patient populations with unmet needs } \\
\text { Cure access to hard-to-reach populations (PWIDs, homeless) } \\
\text { Scale-up programs with disease eradication goals }\end{array}$ \\
\hline Societal & $\begin{array}{l}\text { Cost-effectiveness potential } \\
\text { Direct and indirect economic impact } \\
\text { Awareness of patients, families, providers and health systems } \\
\text { Reductions in stigma } \\
\text { Integration and expansion of harm reduction programs }\end{array}$ \\
\hline
\end{tabular}

ESLD: end-stage liver disease; HCC: hepatocellular carcinoma; AI: auto-immune; PCT: porphyria cutanea tarda; PWIDs: people who inject drugs

analysis studies, however, demonstrated that (1) HCV cure following DAA therapy in patients with cirrhosis reduces HCC risk to a similar extent as interferon (IFN)-based cure (estimated at 63\%-77\% reduction); and (2) the beneficial impact on HCC incidence should be markedly higher in the DAA era, given the greater extent that cirrhosis populations are treated with DAAs, and the higher cure rates among these high risk patient ${ }^{[65]}$. Expanded use of DAAs will solidify the evidence in favor of decreased HCC risk following DAAbased virologic cure, as exemplified by the study findings of Backus et al ${ }^{[66]}$, which showed a $83.5 \%$ reduction in HCC diagnosis following DAA therapy.

Applying interferon-based HCV therapy among people who inject drugs (PWID) was extremely challenging due to patient, provider, health system, structural, and societal barrier ${ }^{[67-69]}$. The availability of DAA therapies with cure rates $>95 \%$ have overcome many of these barriers for PWID as they have fewer psychiatric side effects, are simpler (oral, once-daily vs. weekly injections), and shorter in duration. In earlier years, interferon-based therapy had been proved to be safe and effective among PWID ${ }^{[70]}$, and results of several recent studies have provided substantial insight about DAA use among several PWID subgroups. Among people receiving opioid substitution therapy (OST) with no recent illicit drug use, post-hoc analyses of phase 2 and 3 trials of DAA therapy have demonstrated that the SVR is similar in those receiving and not receiving OST $^{[71-75]}$. In the first phase 3 trial to evaluate DAA therapy in people receiving OST, including those with ongoing drug use, treatment completion was 96\%, 97\% demonstrated $>95 \%$ adherence, and the overall SVR was $91 \%{ }^{[71]}$. Real-world results, among people with a history of injecting drug use (with and without recent drug use), indicated overall treatment completion rates of $93 \%-100 \%$ and SVR rates of $80 \%-96 \%{ }^{[76-79]}$. In studies focused on people with recent injecting drug use, $95 \%-96 \%$ of participants completed therapy with SVR rates of $93 \%-94 \%{ }^{[80,81]}$. Mathematical modelling adds further support to this strong body of evidence. According to these models, modest scale-up of DAA treatment to 8 per 100 PWID years could lead to substantial reductions in HCV prevalence within these populations, thereby preventing transmission and lowering HCV incidence ${ }^{[82,83]}$. Guidelines from the World Health Organization (WHO), the American Association for the Study of Liver Disease/Infectious Diseases Society of America, the European Association for the Study of the Liver, and the International Network for Hepatitis in Substance Users now recommend DAA treatment for PWID ${ }^{[84-87]}$.

While associations between virologic cure and decreased the risk of liver disease-related death have been established during the interferon-era, all-cause mortality is still the most definite clinical end point with clear interpretation, and an important parameter in considering efforts for DAA treatment scale-up ${ }^{[50]}$. Van 
der Meer et al. ${ }^{[50]}$ were able to detect all-cause mortality benefit among patients with chronic HCV infection and advanced hepatic fibrosis who achieved SVR to interferon-based treatment. However, the retrospective nature of the study could have led to selection of a relatively healthy cirrhotic HCV population, because interferon therapy is contraindicated in patients with moderate to severe cirrhosis ${ }^{[50]}$. This selection bias is minimized by DAA therapies due to improved safety and efficacy profiles, even among patients with higher Model for End-Stage Liver Disease (MELD) scores. There is much anticipation to observe data regarding both all-cause and liver-related survival benefits, as the experience with DAA therapy accumulates. At the latest European Association for the Study of the Liver conference, Calvaruso et al ${ }^{[88]}$ reported results from a large real-world setting cohort with patients using a variety of DAA regimens. According to the authors, achieving SVR significantly reduced mortality from both liver disease-related and unrelated causes at all stages of liver fibrosis. In another report from the same conference, the European Liver Transplant Registry reported that, while the total number of liver transplants performed in Europe remained stable over the last decade, the percentage of transplants related to HCV fell significantly from $23 \%$ in the interferon era to $11 \%$ in the DAA era ${ }^{[89]}$.

\section{BARRIERS TO HCV ELIMINATION}

The global burden of viral hepatitis is increasing since 1990, reaching 1.46 million deaths in 2013, exceeding that of HIV (1.3 million), tuberculosis (1.2 million) and malaria (0.5 million deaths). HCV is responsible for approximately $30 \%$ of the overall viral hepatitis mortality ${ }^{[00]}$. The advent of DAA therapy and its extraordinary clinical impact hold promise that HCV elimination as a public health threat is a reachable goal by 2030 . According to the global health sector strategy on viral hepatitis 2016-2021, HCV elimination can be achieved by diagnosing $90 \%$ of people infected and treating $80 \%$ of the people diagnosed. Such a strategy is predicted to reduce new infections by $90 \%$ and mortality by $65 \%{ }^{[9]}$. This report also established a baseline for tracking progress of this global strategy, where only $20 \%$ (14 million) of 71 million people living with chronic HCV knew their diagnosis and a disappointing 7.4\% of those diagnosed (1.1 million) started HCV treatment in 2015.

DAAs can only benefit patients who are screened, diagnosed, linked to care, engaged in care and treated ${ }^{[91]}$. The HCV care cascade concept, adapted from public health efforts in HIV, identifies multiple missed opportunities to address the HCV burden at local, national and global levels ${ }^{[92,93]}$. In order for each HCV infected individual to move down the cascade from diagnosis to HCV treatment, a myriad of variables interact with each other in multifaceted ways. Adapted health care utilization frameworks, such as the Gelberg-Andersen model, are useful tools to examine and understand factors influencing the impact of specific care actions (such HCV screening, linkage to care, engagement, treatment initiation) among vulnerable, high-risk populations ${ }^{[94]}$. Health care utilization is in general influenced by traditional predisposing (ethnicity, age, education, gender), enabling factors (source of care, health insurance, income) as well as need (perceived health, medical conditions, awareness of HCV-positive status). For instance, progressive movement of HCV-positive homeless individuals down the cascade would also be influenced by additional, more specific predisposing (histories of child abuse, jail/prison, drug and alcohol use, mental illness, and risky sexual behavior), and enabling factors (barriers to care, competing needs, lack of housing, food security, and case management). It is known that the many of the highest HCV prevalent populations (i.e., PWID, homeless and socioeconomically disadvantaged) often lack access to HCV testing and continuity of care ${ }^{[94]}$. Case management and regular sources of care attenuates social vulnerability, and robust support systems are needed in response to these complex and challenging demands ${ }^{[95-97]}$.

Several determinants of health care utilization among vulnerable individuals, including illicit drug use, often introduce stigma to the care cascade equation, furthering the hardships of those in need of HCV care and curr $^{[98]}$. Perceived stigma associated with HCV infection leads to anxiety, fear of transmission to others, reduced intimacy in relationships, denial (reluctance to seek medical care for addiction and/or HCV 
treatment) and social isolation ${ }^{[99]}$. People living with HCV are frequently blamed for the disease, putting themselves at risk to acquire HIV infection, and viewed as irresponsible, not accountable, "unworthy" Perceived and real stigma towards HCV, within families and workplaces, affect self-esteem and quality of life, causes delay or impediment to timely diagnosis and treatment, and leads to continuing risk of disease transmission ${ }^{[102]}$. The response to stigma requires broad-based, societal educational efforts in order to increase the understanding of this disease, still connected to several pejorative stereotypes ${ }^{[103,104]}$. These efforts are expected to bring greater compassion, patient-centered healthcare, and improved coping skills to people living with $\mathrm{HCV}^{[105]}$.

Among the 71 million people infected globally, there is a large burden of HCV infection among PWID, with a $50 \%$ prevalence of chronic infection, representing an estimated 5.6 million individuals - $8 \%$ of all infections globally ${ }^{[106]}$. There is also a large and unquantified number of chronic infections among PWID who have ceased injecting, and HCV morbidity and mortality continues to rise among recent and former PWID ${ }^{[107]}$. In 2015, there were 1.7 million new HCV infections globally - this is a greater number than patients who were started on treatment in the same year - with $23 \%$ of these new infections attributable to current injecting drug use in many settings ${ }^{[9,108-111]}$. Along with unsafe healthcare practices and injections, intravenous drug use is a leading contributor to HCV incidence, especially in the European and Eastern Mediterranean Regions $^{[9]}$. Even in areas of the world where the incidence was low in 2015, an increase in transmission may occur at any time, due to epidemic spread associated with injection drug use. Despite years of HCV decline in the US, the incidence of HCV infection doubled between 2010 and 2014, due to an intensifying opioid epidemic and rise in injecting drug use behavior ${ }^{[112]}$. The number of reported cases of acute HCV among persons reporting injection drug use has increased, particularly in rural areas ${ }^{[113,114]}$. In the US, injection drug use among PWID has resulted in rapid dissemination of HIV and HCV, as well as some transmission of hepatitis B virus $(\mathrm{HBV})^{[15,116]}$. There have been few studies evaluating the HCV cascade of care among PWID, and contemporary studies from Australia and Kentucky has similarly shown high prevalence of antibody positivity, poor rates of viral load confirmation and minimal rates of treatment uptake, both during the interferon era and in the first few years of the DAA era ${ }^{[117,118]}$. In the Netherlands, access and reimbursement for DAA therapy occurred earlier (since 2014) than many other countries, and cohorts of PWID have been well-characterized. Despite rates of viral load testing as high as $95 \%$ among seropositive individuals, DAA uptake has remained low, largely limited by fibrosis staging restrictions that were in effect until October 2015 and subsequently lifted ${ }^{[119]}$.

Transmission of HCV among men who have sex with men (MSM) infected with HIV has also been reported in Europe, Australia and the US as well as reinfection among HIV-infected MSM who were successfully cured with treatment for hepatitis ${ }^{[120,121]}$. No estimates are available to quantify how much this emerging issue contributes to the overall transmission of $\mathrm{HCV}^{[122,123]}$. The observed risk of reinfection in HIV-infected MSM during the interferon era ranged from 5.3 to $13.2 / 100$ persons years ${ }^{[121,124,125]}$, including subgroups with multiple HCV reinfections and at risk of transmission of HCV virus with resistant variants ${ }^{[121,126]}$. These reinfection rates are higher than the rates observed in retrospective and prospective studies of PWID treated for chronic HCV infection, ranging from 1.21 to $4.9 / 100$ persons years ${ }^{[127-130]}$. The role of HIV infection in increasing the risk of HCV reinfection is likely associated with an approximately threefold reduction in rates of spontaneous clearance following acute HCV infection, as well as high-risk sexual practices among predominantly male cohorts representing HIV-infected $\mathrm{MSM}^{[131,132]}$. Traditionally, individuals at risk of reinfection have been grouped as either HIV-infected MSM or PWID; however, there is clearly a subset of HIVinfected men who both use injection drugs and have sex with men. As such, interventions targeted at both safer sexual practices and safer drug use practices are indicated among HIV-infected MSM.

HCV is highly prevalent among incarcerated populations, with global prevalence over $10 \%$, and considerably higher among incarcerated PWID ${ }^{[133-135]}$. Globally, more than 10 million people are incarcerated on a daily basis, with many more annually, making prisons a key setting for implementation of HCV elimination strat- 
egies ${ }^{[136]}$. The close relationship between injecting drug use, incarceration, and prevalence of blood-borne viruses makes correctional centers a crucial setting for enhanced DAA therapy access and broad prevention strategies $^{[134]}$. The United Nations Basic Principles for the Treatment of Prisoners state that prisoners "shall have access to the health services available in the country without discrimination on the grounds of their legal situation ${ }^{,[137]}$. Unfortunately, this principle has been infrequently applied in real life and in most countries prisoners have a lesser possibility of assistance and care than other citizens ${ }^{[138]}$. Once in prison, overcrowding, violence, separation from family and emotional problems are additional reasons that may induce inmates to start or continue unsafe habits, fueling high incidence rates that exceeds 30 per 100 persons per year ${ }^{[139-141]}$. Proper treatment of chronic hepatitis $C$ in prison is rare due to social and educational reasons and, not least, because most inmates with HCV infection remain unaware of their status, and several other barriers (drug abuse, stress, fear, lack of confidence, stigma, difficulty to relate to the health personnel) adds up to the lack of liver disease specialists in prison ${ }^{[142-145]}$. Although many prisoners are incarcerated for long periods, the average length of stay can be shorten to weeks or months in several cases, which makes it difficult to complete the clinical itinerary from screening to post-treatment follow-up ${ }^{[146,147]}$.

Compared to interferon, DAA therapies are easier to roll out in community and outreach settings, but in reality there is a significant lack of experience and engagement in routine HCV screening and treatment in primary care, and misconceptions about whom to screen, risk of progression of liver disease or therapy itself in this setting ${ }^{[148-150]}$. Even specialists in liver disease may have limited experience treating HCV, or be selective about which patients they consider as good candidates for therapy and fail to recommend treatment because of concerns about nonadherence, drug use or risk of re-infection ${ }^{[151,152]}$. Furthermore, there are insufficient numbers of providers who can and are willing to treat HCV, and insufficient resources for case managers, navigators and social workers in suitable capacity to attend a growing demand of patients in need of treatment ${ }^{[153]}$.

All-oral treatments are very expensive, with initial wholesale acquisition cost (WAC) of 90,000 US dollars per 3 months treatment course (or $\$ 1000 /$ pill). While the prices of DAAs have decreased rapidly in some countries, they remain variably expensive and remain unaffordable in others ${ }^{[154]}$. In the US for example, DAA pricing is influenced by a chain of multiple organizations, including pharmaceutical companies (who determine the WAC), Pharmacy Benefit Managers (PBMs) (intermediaries between the former and health insurance companies), insurance companies (who determine the preferred choice of regimens and out-ofpocket expenses for patients), and specialty pharmacies (who receive dispensing fees and may contract with insurance companies, PBMs, or pharmaceutical companies to provide adherence support, management of adverse effects, and outcome measurements). In this system chain, negotiated drug prices are held as confidential business contracts, with no transparency regarding the actual prices paid for hepatitis $\mathrm{C}$ drugs. Nevertheless, the recently observed increases in WAC discounts or rebates have implied a reduction in drug costs to payers ${ }^{[85,155,156]}$. In other countries, pharmaceutical companies negotiate pricing directly with the payers (usually a nationalized system), where licensing agreements may allow for production of generic formulations and transparency in negotiated cost of drugs to payers ${ }^{[155,157]}$. Increasing generic competition has lowered DAA price, but those remain high (tens of thousands of dollars per treatment course) in developed countries, in those middle-income countries that do not have access to generic formulations, and in those countries who fall outside of license agreements. This creates a heavy financial burden on many health systems and leads to treatment rationing ${ }^{[154]}$. Comparatively, generic versions of new HCV medicines have been available for under 500 US dollars per patient in some countries, and the production cost of two DAAs could be as low as 200 US dollars per patient. Hence, further price reductions could be achieved and will be needed to increase the number of patients treated ${ }^{[157]}$.

In addition to drug cost, the cost of diagnosis and disease evaluation also represent an important financial burden, especially in low to middle income countries (LMICs), which has brought uncertainty as to the opti- 
mal testing approaches and who to prioritize for testing in this setting ${ }^{[158]}$. Diagnostic testing involves laboratory-based immunoassays required to meet minimum safety, quality and performance standards, and rapid diagnostic tests (RDT) with important role in settings where there is limited access to laboratory infrastructure and/or in populations where access to rapid testing would facilitate linkage to care and treatment ${ }^{[158]}$. Directly following a reactive HCV antibody serological test result, the use of quantitative or qualitative nucleid acid testing (NAT) for detection of HCV RNA is recommended as the preferred strategy to diagnose viraemic infection and monitor treatment response. An assay to detect HCV core (p22) antigen, which has comparable clinical sensitivity to NAT, is an alternative to NAT to diagnose viraemic infection ${ }^{[159]}$. According to recent WHO guidelines, focused serologic testing with HCV antibody (anti-HCV) should be offered with linkage to prevention, care and services to high-risk populations; general population testing should be approached in settings of high prevalence in the general population ( $2 \%-5 \%$ infection prevalence); and birth cohort testing should be applied to specific identified birth cohorts of older persons at higher risk of infection and morbidity within populations that have an overall lower general prevalence ${ }^{[158,159]}$. Such testing strategies, although incurring in significant cost if applied to massive testing scale-up, should still hold reasonable cost-effectiveness tailored to broad variations in gross domestic product worldwide, although there is lack of evidence among LMICs ${ }^{[158]}$. Interestingly, studies have shown that the cost-effectiveness of testing for HCV seems most sensitive to variations in prevalence, treatment efficacy, progression rates from chronic $\mathrm{HCV}$ to cirrhosis, and levels of linkage to care and treatment, and relatively insensitive to costs of screening and treatment ${ }^{[158,160-162]}$. Another barrier to HCV testing and evaluation scale-up is the cost involved in HCV genotype ascertainment. This is required for a number of DAA regimens available, and certainly makes the use pan-genotypic regimens an attractive cost-effective option, especially in countries with high prevalence of non-GT1 HCV, that could potentially bypass genotype confirmation ${ }^{[163]}$. Simplifying testing algorithms and lowering the cost of monitoring can dramatically cut costs of treatment for HCV in the future. For instance, the cost of the current step-wise evaluation algorithms (screening for exposure using serology or RDT; quantitative NAT testing for viremia confirmation, monitoring, efficacy assessment; and genotyping) can be as high as 220-1100 USD; whereas the cost of potential future scenarios (screening for exposure using serology, RDT, oral fluids or dried blood spots; qualitative NAT for viremia confirmation without genotyping, minimal viral load monitoring and efficacy assessment) could be as low as $15-75$ USD $^{[164]}$.

\section{PROGRESS IN PUBLIC HEALTH RESPONSE}

Public health strategies addressing the remarkable challenges of HCV elimination has leveraged sound epidemiological data, detailed expert opinion input and mathematical modelling. In order to inform treatment and prevention strategies, as well as public health policy, efforts have focused on gathering country-specific

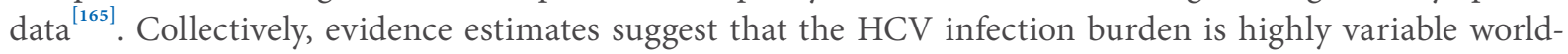
wide. For instance, the population prevalence of HCV viremia seems to range widely, from $0.3 \%$ in Austria, England, Germany and France to $7.3 \%$ in Egypt. The latter country is clearly unique, even when compared to Portugal, Brazil and the US with viremia prevalence nearing $1.0 \%-1.2 \%^{[166,167]}$. Within the estimated viremic population, there are also significant variations in the estimated rates of individuals newly diagnosed in each country (3\%-14\% per year) and treated $\left(1 \%-11 \%\right.$ per year) ${ }^{[167,168]}$. Liver fibrosis burden is also estimated to be greater in countries with more generalized, older epidemics such as Egypt and Brazil, in opposition to younger epidemics with large contributions of PWIDs (Australia, Czech Republic and Australia) ${ }^{[166]}$. While the overall number of new HCV infections is expected to decline worldwide, the number of cases with advanced liver disease is expected to increase ${ }^{[169]}$. This dichotomy and epidemiological contrasts between countries is fueled by high cumulative prevalence, reason why the global strategy calls for significant reductions of both the number of new infections and HCV-related mortality.

Modeling-based evidence, calibrated by country-specific epidemiological data, shows that sizable reductions in incidence, morbidity and mortality can only occur if high-efficacy therapies are combined with increased diagnosis and treatment access. Yearly treatment rates in the order of $10 \%$ are likely to position most coun- 
tries on track to achieve HCV elimination targets. However, this is estimated to require a 3 to 5 -fold increase in diagnosis and/or treatment rates from baseline; and robust, highly inclusive public health programs, focused on hard-to-reach populations and PWIDs ${ }^{[167,83]}$. Much progress is needed to make HCV elimination an explicit and adequately resourced public health priority, using appropriate means at all levels through collaborations between individual citizens, civil society organizations, researchers, healthcare professionals, the private sector, local and national governmental bodies ${ }^{[170]}$. Countries have been challenged to disseminate models of enhanced screening and DAA delivery in and outside tertiary care settings, such as community primary care ${ }^{[171]}$, nurse-led models of care $^{[172]}$ and prisons ${ }^{[173]}$. Studies have demonstrated the utility of nurse-physician partnerships and training programs to improve engagement in HCV care, translated into high proportions of patients receiving counselling, education, and successful treatment with cure rates comparable to contemporary clinical trials, during the interferon and early DAA eras ${ }^{[171,174-176]}$. The results of the ASCEND trial suggested that DAAs can be independently administered by primary care physicians and nurse practitioners to challenging sub-populations, setting the foundation to HCV micro-elimination interventions such as the one carried out within the Cherokee Nation Health Services system ${ }^{[177,178]}$. HCV elimination should not be an impossible task if taken as a "think global, act local" approach, in which clinics are structured to support vulnerable populations, also in connection with harm reduction venues in the form of needle and syringe services programs (NSP) and co-location of treatment to OST clinics ${ }^{[179]}$. For example, Iceland's geographical isolation and relatively small population- comparable in size to many cities globally - makes it an important case study. In general, Iceland provide favorable conditions for geographicallytargeted policies to reduce transmission among PWID (setting up testing and treatment programs, NSPs and OST in consultation with local healthcare and community service providers) without the unpredictable bias of population mobility to and from areas with varying program coverages or HCV epidemiology within the same country ${ }^{[180]}$. It is estimated that DAA scale-up to levels already being experienced, coupled with reasonable efforts to diagnose and treat PWIDs, could turn Iceland one the first countries to eliminate HCV as early as $2020^{[181]}$.

The European Union (EU) rely on advanced health-care infrastructure, and is uniquely poised to eliminate $\mathrm{HCV}^{[182]}$. Estimates indicate that over one million people had been identified with positive viremic status by 2015 (36\% of total viremic pool) and 133,000 were cured in 2015 alone (4\% of the total infected population or $9 \%$ of the diagnosed population). The number of cures in that year was higher than the estimated number of new infections $(\sim 58,000)$ added to the number of HCV-infected immigrants $(\sim 30,000)$ believed to have entered the EU. Austria, France, Germany, Netherlands and Spain have led the way with at least $8 \%$ of infected individuals cured in 2015. But many other countries (Bulgaria, Croatia, Czech Republic, Finland, Hungary, Latvia, Lithuania, Poland, Romania, Slovakia) have seen greater estimated numbers of new infections than the number of people cured. In order for the EU to be on track with WHO targets by 2025, unrestricted treatment still needs to increase by $25 \%$ until then, and annual new diagnosis rates by 2 -fold compared to 2015 baseline ${ }^{[182]}$.

In Australia, an active HCV screening program has led to $82 \%$ of HCV-infected population being diagnosed, placing the country on-track to achieve WHO elimination targets. The Australian unrestricted DAA program, launched in March 2016, adopts a fixed priced approach where the country pays a single fee for ad lib access to as much DAA therapy as it can use over a fixed period of time. This approach eliminates the "fee for service" model and instead uses a public health model that incentivizes patients and providers to employ universal screening and treat all who test positive. This has resulted in an estimated 58,500 individuals (26\% of total HCV-infected population) initiating treatment through 2017. Treatment uptake has been high among sub-populations at greater HCV transmission risk (22\% of PWIDs and $>60 \%$ of those with HIV/HCV coinfection initiated DAA treatment in 2016) and the country has enhanced surveillance efforts to track the program's future results. It is estimated that Australia could eliminate HCV from the continent by $2020^{[183]}$. 
In the United States, an estimated 260,000 people have received HCV treatment in 2015. This significant treatment volume was mostly due to large uptake of patients with advanced liver fibrosis who had been waiting for DAAs to become available ${ }^{[184]}$. Progress estimates towards elimination in the US are greatly impacted by significant increases in HCV incidence experienced from 2011 (16,000 new cases) to 2014 (31,000 new cases), largely driven by the opioid epidemic ${ }^{[185]}$. Assuming that the rates of new infection remain the same in the next 14 years, the US can only achieve WHO targets by 2030 if it expands screening to diagnose 80\% of individuals infected ( $50 \%$ of infected individuals are diagnosed at baseline), provides unrestricted treatment for all, and maintains the number of treated patients at least 150,000 per year ${ }^{[184,186]}$. The Veterans Affairs Health System has taken on robust efforts to increase funding, negotiate reduced costs per cure, screen the majority of patients at risk, expand treatment capacity by utilizing primary care and pharmacy services and have offered unrestricted treatment to $75 \%$ their patients in need ${ }^{[187]}$. In coordination with the Center for Disease Control and Prevention and the Viral Hepatitis National Plan, multiple ongoing federal and nonfederal initiatives take on similar efforts to make a dent in local HCV epidemics across the US ${ }^{[188]}$.

In 2016, roughly 40,000 Egyptians died of the disease, and nearly 4.5-5 million are currently infected - the highest burden in the world for Egypt's population size ${ }^{[189]}$. Following successful negotiations between government and drug makers in 2014, DAAs have become widely available at markedly reduced prices. Since then, more than a million Egyptians have been treated ${ }^{[190]}$. In addition to lowering the cost of drugs, Egypt has succeeded in opening new treatment centers, creating electronic portals to enroll patients, and expanding its domestic pharmaceutical industry to ensure a steady pipeline of affordable medications ${ }^{[191]}$.

Georgia, another country with high HCV prevalence, initiated in April 2015 the world's first program to eliminate hepatitis. With technical assistance from Centers for Disease Control and Prevention (CDC) and key partnership with drug industry to provide DAAs free of charge, the ambitious goal was defined as a $90 \%$ reduction in HCV prevalence by $2020^{[192,193]}$. From April 2015 through December 2016, a total of 27,595 persons initiated treatment for HCV infection, among whom 19,778 (71.7\%) completed treatment. The number of persons initiating treatment peaked in September 2016 at 4,595 and declined during October-December. Broader implementation of interventions that increase access to HCV testing, care, and treatment for persons living with $\mathrm{HCV}$ are needed for Georgia to reach national targets for the elimination of $\mathrm{HCV}^{[194]}$. Brazil, with an estimated burden of 657,000 people infected, and enhanced DAA access through public health system able to negotiate $90 \%$ cost reduction in drug prices, hosted the World Viral Hepatitis Summit in 2017, and presented care cascade estimates that places the country on track of disease elimination by 2030, along with Australia, Egypt, Georgia, Germany, Iceland, Japan, the Netherlands and Qatar ${ }^{[195]}$. Taken together, these examples suggest that the largest hurdle to eliminating HCV is the cost of medications, impeding access to therapy in locations where the cost of drugs remains prohibitively expensive.

\section{SURVEILLANCE, ADVOCACY AND POLICY GAPS}

As mentioned above, political will to optimize DAA treatment access and reduce costs per cure has been a main driver for the witnessed public health progress. However, much more needs to be accomplished to ensure that the hepatitis treatment goals are reached on a global level. Currently, treatment priorities aim to improve outcomes for individuals with more advanced disease progression. This treatment prioritization aimed at the individual-level misses the opportunity to reduce incident infections at the population level through treatment as prevention aimed at individuals largely driving new infections (i.e., PWID). Treatment prioritization for those with severe liver disease is supported by cost-effectiveness analyses that exclusively accounts for individual health benefits of HCV treatment. These analyses show that treatment of moderate to severe disease is cost-effective but, at high HCV treatment costs, treatment of mild disease should be delayed ${ }^{[196]}$. However, due to the relatively long duration of HCV disease progression compared with durations of risk behavior (such as injecting drug use), treatment of those with advanced liver disease is unlikely to have prevention benefit ${ }^{[197]}$. On the other hand, models of HCV transmission that incorporate both indi- 
vidual and population prevention benefit show that treating PWID could avert secondary infections (treatment as prevention) and be more cost-effective in many settings (where chronic HCV is at $40 \%$ prevalence or less among PWID) than treating other patient groups ${ }^{[198]}$. Therefore, the public response we have seen thus far creates many opportunities to reach liver mortality reduction targets by 2030, but also many challenges in reaching incidence reduction targets in the same time span. This needs to include unrestricted access to DAAs on a global scale and, in particular, enhanced HCV screening to identify the large proportion of hardto-reach and undiagnosed individuals. Without a change in public policy that focus on reducing incident HCV infections, eradicating HCV as a pathogen will be near impossible ${ }^{[199]}$. A survey of patient advocacy groups from 25 different European Countries, has recently highlighted several specific policies and program gaps in support of elimination efforts. Although fewer countries (8 out of 25) were reported to refuse treatment to people who are currently injecting drugs in 2017, nearly half of these nations were reported to lack a national HCV strategy, and the majority of them lack key components of comprehensive strategies such as disease registries, syringe exchange programs available in all parts of the country, DAA treatment availability in non-hospital settings, and unrestricted access to DAAs ${ }^{[200]}$.

Much of what is known about public health responses in HCV is based on modeling studies that are limited in their essence to be useful approximations of reality ${ }^{[201]}$. Accurate program evaluations towards disease elimination will require robust surveillance systems. Case reporting, based on regular notification by clinicians and laboratories, serological surveys and cancer and death registries are important for measuring the impact of hepatitis infections and evaluating the efficacy of interventions ${ }^{[202]}$. However, viral hepatitis surveillance shortcomings have resulted in many WHO Member States (MS) having insufficient data available to guide decision-making ${ }^{[203]}$. Among MS in the WHO European Region, key surveillance components currently exist with more than $90 \%$ of MS conducting surveillance for acute HBV and HCV infections; however, substantial systemic shortcomings were reported as well, especially in regions where the surveillance of chronic HBV and HCV infections was less common ${ }^{[204]}$. Viral hepatitis surveillance systems historically have focused on collecting data on acute infections, primarily for the purpose of identifying outbreaks, suggesting that surveillance systems may not be evolving rapidly enough to keep pace with recent developments in viral hepatitis prevention and treatment ${ }^{[205]}$. Besides, the accurate classification of viral hepatitis infection as acute versus chronic is a widely recognized challenge, especially for hepatitis C, and only a minority of MS have no hepatitis cases reported as "undifferentiated" or "unclassified" ${ }^{\text {206] }}$. In the US, HCV surveillance has been ongoing since 1982, but the program for chronic disease surveillance is underfunded as only seven jurisdictions receive support from the CDC. Additionally, local health departments are responsible for reporting to the CDC, and the data aggregation across health departments from different governmental levels is not always accurate ${ }^{[207]}$. A greater focus on chronic disease surveillance would contribute to better understand the disease burden, assess the impact of prevention and treatment efforts, and maximize the impact of resources $^{[208]}$.

\section{CONCLUSION}

The advent of the DAA era sparked serious efforts towards elimination of HCV infection by 2030, which can become a reality with expanded use of DAAs. All-oral regimens have proven safe and effective in treating key HCV-infected subpopulations, including PWIDs, and allow for cure opportunities to nearly all infected patients with hepatitis C. Programmatic prospects of disease elimination will face many challenges, including: an extraordinary and ever increasing disease burden, the stigmatizing nature of the infection which challenges diagnosis, multiple societal and individual barriers to access care, and, perhaps most importantly, the high treatment costs. Unprecedented progress towards HCV elimination has been experienced in recent years, but only few countries are currently considered to be on track for disease elimination by 2030 . Worldwide, countries are investigating strategies to scale-up efficient HCV screening and treatment to the levels necessary to reduce both HCV mortality and incidence. Fundamental changes in societal views, political will, surveillance and adoption of a public health treatment mindset, with sharp reduction in the cost of DAA therapy, will be required for HCV elimination worldwide. 


\section{DECLARATIONS}

\section{Authors' contributions}

Design, literature research, manuscript writing: Franco RA

Manuscript editing: Galbraith JW, Overton ET

Manuscript revision: Saag MS

\section{Availability of data and materials}

Not applicable.

\section{Financial support and sponsorship}

None.

\section{Conflicts of interest}

Franco RA is has served as a consultant to Gilead and Bristol Myers-Squibb and is an investigator on grants paid to his institution from Gilead, Merck and Janssen; Galbraith JW has served on Gilead and AbbVie advisory boards and received grants from Gilead Sciences paid to his institution; Overton ET receives research support for the National Institute of Health, Gilead, Merck and Abbvie paid to his institution and has served as a consultant to Gilead and ViiV; Saag MS is a scientific advisor to Gilead, Merck, and ViiV, and principal investigator on grants paid to his institution from Gilead, Merck, and ViiV.

\section{Ethical approval and consent to participate}

Not applicable.

\section{Consent for publication}

Not applicable.

\section{Copyright}

(C) The Author(s) 2018.

\section{REFERENCES}

1. Polaris Observatory HCV Collaborators. Global prevalence and genotype distribution of hepatitis C virus infection in 2015: a modelling study. Lancet Gastroenterol Hepatol 2017;2:161-76.

2. Gower E, Estes C, Blach S, Razavi-Shearer K, Razavi H. Global epidemiology and genotype distribution of the hepatitis C virus infection. J Hepatol 2014;61:S45-57.

3. Stanaway JD, Flaxman AD, Naghavi M, Fitzmaurice C, Vos T, et al. The global burden of viral hepatitis from 1990 to 2013: findings from the Global Burden of Disease Study 2013. Lancet 2016;388:1081-8.

4. Bukh J, Miller RH, Purcell RH. Genetic heterogeneity of hepatitis C virus: quasispecies and genotypes. Semin Liver Dis 1995;15:41-63.

5. Freeman AJ, Marinos G, Ffrench RA, Lloyd AR. Immunopathogenesis of hepatitis C virus infection. Immunol Cell Biol 2001;79:515-36.

6. Maylin S, Martinot-Peignoux M, Moucari R, Boyer N, Ripault MP, et al. Eradication of hepatitis C virus in patients successfully treated for chronic hepatitis C. Gastroenterology 2008;135:821-9.

7. Grebely J, Prins M, Hellard M, Cox AL, Osburn WO, et al. Hepatitis C virus clearance, reinfection, and persistence, with insights from studies of injecting drug users: towards a vaccine. Lancet Infect Dis 2012;12:408-14.

8. Afdhal NH, Zeuzem S, Schooley RT, Thomas DL, Ward JW, et al. The new paradigm of hepatitis C therapy: integration of oral therapies into best practices. J Viral Hepat 2013;20:745-60.

9. WHO. Global health sector strategies on viral hepatitis 2016-2021. Available from: https://www.who.int/hepatitis/strategy2016-2021/ ghss-hep/en/. [Last accessed on 28 Nov 2018]

10. Lok AS, Gardiner DF, Lawitz E, Martorell C, Everson GT, et al. Preliminary study of two antiviral agents for hepatitis C genotype 1 . N Engl J Med 2012;366:216-24.

11. Choo QL, Kuo G, Weiner AJ, Overby LR, Bradley DW, et al. Isolation of a cDNA clone derived from a bloodborne non-A, non-B viral hepatitis genome. Science 1989;244:359-62.

12. Major ME, Feinstone SM. The molecular virology of hepatitis C. Hepatology 1997; 25:1527-38.

13. Lohmann V, Körner F, Koch J, Herian U, Theilmann L, et al. Replication of subgenomic hepatitis C virus RNAs in a hepatoma cell line. Science 1999;285:110-3.

14. Götte M, Feld JJ. Direct-acting antiviral agents for hepatitis C: structural and mechanistic insights. Nat Rev Gastroenterol Hepatol 2016;13:338-51. 
15. Wyles DL, Ruane PJ, Sulkowski MS, Dieterich D, Luetkemeyer A, et al. Daclatasvir plus sofosbuvir for HCV in patients coinfected with HIV-1. N Engl J Med 2015;373:714-25.

16. Rockstroh JK, Nelson M, Katlama C, Lalezari J, Mallolas J, et al. Efficacy and safety of grazoprevir (MK-5172) and elbasvir (MK8742) in patients with hepatitis C virus and HIV co-infection (C-EDGE CO-INFECTION): a non-randomised, open-label trial. Lancet HIV 2015;2:e319-27.

17. Rockstroh JK, Lacombe K, Viani RM, Orkin C, Wyles D, et al. Efficacy and safety of glecaprevir/pibrentasvir in patients coinfected with hepatitis C virus and human immunodeficiency virus type 1: the EXPEDITION-2 study. Clin Infect Dis 2018;67:1010-7.

18. Osinusi A, Townsend K, Kohli A, Nelson A, Seamon C, et al. Virologic response following combined ledipasvir and sofosbuvir administration in patients with HCV genotype 1 and HIV co-infection. JAMA 2015;313:1232-9.

19. Naggie S, Cooper C, Saag M, Workowski K, Ruane P, et al. Ledipasvir and sofosbuvir for HCV in patients coinfected with HIV-1. N Engl J Med 2015;373:705-13.

20. Sulkowski MS, Eron JJ, Wyles D, Trinh R, Lalezari J, et al. Ombitasvir, paritaprevir co-dosed with ritonavir, dasabuvir, and ribavirin for hepatitis C in patients co-infected with HIV-1: a randomized trial. JAMA 2015;313:1223-31.

21. Lawitz E, Sulkowski MS, Ghalib R, Rodriguez-Torres M, Younossi ZM, et al. Simeprevir plus sofosbuvir, with or without ribavirin, to treat chronic infection with hepatitis $\mathrm{C}$ virus genotype 1 in non-responders to pegylated interferon and ribavirin and treatment-naive patients: the COSMOS randomised study. Lancet 2014;384:1756-65.

22. AASLD/IDSA. Sofosbuvir/velpatasvir fixed dose combination for 12 weeks in patients co-infected with HCV and HIV-1: the phase 3 ASTRAL-5 study abstract PS104. Available from: https://www.hcvguidelines.org/references/wyles-2016. [Last accessed on 28 Nov 2018]

23. Charlton M, Everson GT, Flamm SL, Kumar P, Landis C, et al. Ledipasvir and sofosbuvir plus ribavirin for treatment of HCV infection in patients with advanced liver disease. Gastroenterology 2015;149:649-59.

24. Manns M, Samuel D, Gane EJ, Mutimer D, McCaughan G, et al. Ledipasvir and sofosbuvir plus ribavirin in patients with genotype 1 or 4 hepatitis $\mathrm{C}$ virus infection and advanced liver disease: a multicentre, open-label, randomised, phase 2 trial. Lancet Infect Dis 2016;16:685-97

25. Bourlière M, Bronowicki JP, de Ledinghen V, Hézode C, Zoulim F, et al. Ledipasvir-sofosbuvir with or without ribavirin to treat patients with $\mathrm{HCV}$ genotype 1 infection and cirrhosis non-responsive to previous protease-inhibitor therapy: a randomised, doubleblind, phase 2 trial (SIRIUS). Lancet Infect Dis 2015;15:397-404.

26. Curry MP, O’Leary JG, Bzowej N, Muir AJ, Korenblat KM, et al. Sofosbuvir and velpatasvir for HCV in patients with decompensated cirrhosis. N Engl J Med 2015;373:2618-28.

27. Feld JJ, Jacobson IM, Hézode C, Asselah T, Ruane PJ, et al. Sofosbuvir and velpatasvir for HCV genotype 1, 2, 4, 5, and 6 infection. N Engl J Med 2015;373:2599-607.

28. Poordad F, Schiff ER, Vierling JM, Landis C, Fontana RJ, et al. Daclatasvir with sofosbuvir and ribavirin for hepatitis C virus infection with advanced cirrhosis or post-liver transplantation recurrence. Hepatology 2016;63:1493-505.

29. Reau N, Kwo PY, Rhee S, Brown RS Jr, Agarwal K, et al. MAGELLAN-2: safety and efficacy of glecaprevir/pibrentasvir in liver or renal transplant adults with chronic hepatitis C genotype 1-6 infection. Hepatology 2017;66:S90-1.

30. Charlton M, Everson GT, Flamm SL, Kumar P, Landis C, et al. Ledipasvir and sofosbuvir plus ribavirin for treatment of HCV infection in patients with advanced liver disease. Gastroenterology 2015;149:649-59.

31. Agarwal K, Castells L, Müllhaupt B, Rosenberg WMC, McNabb B, et al. Sofosbuvir/velpatasvir for 12 weeks in genotype 1-4 HCVinfected liver transplant recipients. J Hepatol 2018;69:603-7.

32. Fontana RJ, Brown RS Jr, Moreno-Zamora A, Prieto M, Joshi S, et al. Daclatasvir combined with sofosbuvir or simeprevir in liver transplant recipients with severe recurrent hepatitis C infection. Liver Transpl 2016;22:446-58.

33. O’Leary JG, Fontana RJ, Brown K, Burton JR Jr, Firpi-Morell R, et al. Efficacy and safety of simeprevir and sofosbuvir with and without ribavirin in subjects with recurrent genotype 1 hepatitis $\mathrm{C}$ postorthotopic liver transplant: the randomized GALAXY study. Transpl Int 2017;30:196-208.

34. Roth D, Nelson DR, Bruchfeld A, Liapakis A, Silva M, et al. Grazoprevir plus elbasvir in treatment-naive and treatment-experienced patients with hepatitis $\mathrm{C}$ virus genotype 1 infection and stage 4-5 chronic kidney disease (the C-SURFER study): a combination phase 3 study. Lancet 2015;386:1537-45.

35. Gane Ed, Lawitz E, Pugatch D, Papatheodoridis G, Bräu N, et al. EXPEDITION-4: efficacy and safety of glecaprevir/pibrentasvir (ABT-493/ABT-530) in patients with renal impairment and chronic hepatitis C virus genotype 1-6 infection. Hepatology 2016;64:1125A.

36. Colombo M, Aghemo A, Liu H, Zhang J, Dvory-Sobol H, et al. Treatment with ledipasvir-sofosbuvir for 12 or 24 weeks in kidney transplant recipients with chronic hepatitis $C$ virus genotype 1 or 4 infection: a randomized trial. Ann Intern Med 2017;166:109-17.

37. Sawinski D, Kaur N, Ajeti A, Trofe-Clark J, Lim M, et al. Successful treatment of hepatitis C in renal transplant recipients with directacting antiviral agents. Am J Transplant 2016;16:1588-95.

38. Goetsch MR, Tamhane A, Varshney M, Kapil A, Overton ET, et al. Direct-acting antivirals in kidney transplant patients: successful hepatitis C treatment and short-term reduction in urinary protein/creatinine ratios. Pathog Immun. 2017;2:366-75.

39. Balistreri WF, Murray KF, Rosenthal P, Bansal S, Lin CH, et al. The safety and effectiveness of ledipasvir-sofosbuvir in adolescents 12-17 years old with hepatitis C virus genotype 1 infection. Hepatology 2017;66:371-8.

40. Wirth S, Rosenthal P, Gonzalez-Peralta RP, Jonas MM, Balistreri WF, et al. Sofosbuvir and ribavirin in adolescents 12-17 years old with hepatitis C virus genotype 2 or 3 infection. Hepatology 2017;66:1102-10.

41. CROI. Retreatment of HCV/HIV-coinfected patients who failed 12 weeks of LDV/SOF. Available from: www.croiconference.org/ sessions/retreatment-hcvhiv-coinfected-patients-who-failed-12-weeks-ldvsof. [Last accessed on 28 Nov 2018]

42. EASL. Sofosbuvir/velpatasvir in combination with ribavirin for 24 weeks is effective retreatment for patients who failed prior NS5A 
containing DAA regimens: results of the retreatment study. Available from: http://www.natap.org/2016/EASL/EASL_11.htm. [Last accessed on 28 Nov 2018]

43. Bourlière M, Gordon SC, Flamm SL, Cooper CL, Ramji A, et al. Sofosbuvir, velpatasvir, and voxilaprevir for previously treated HCV infection. N Engl J Med 2017;376:2134-46.

44. AASLD/IDSA. ENDURANCE-1: efficacy and safety of 8- versus 12-week treatment with ABT-493/ABT-530 in patients with chronic HCV genotype 1 infection [Abstract 253]. Available from: https://www.hcvguidelines.org/references/zeuzem-2016. [Last accessed on 28 Nov 2018]

45. Poordad F, Felizarta F, Asatryan A, Sulkowski MS, Reindollar RW, et al. Glecaprevir and pibrentasvir for 12 weeks for hepatitis C virus genotype 1 infection and prior direct-acting antiviral treatment. Hepatology 2017;66:389-97.

46. Poordad F, Pol S, Asatryan A, Buti M, Shaw DR, et al. MAGELLAN-1, part 2: glecaprevir and pibrentasvir for 12 or 16 weeks in patients with chronic HCV genotype 1 or 4 and prior direct-acting antiviral treatment failure. Gastroenterology 2017;152:S1057.

47. Rice CM, Saeed M. Hepatitis C: treatment triumphs. Nature 2014;510:43-4.

48. Poynard T, McHutchison J, Manns M, Trepo C, Lindsay K, et al. Impact of pegylated interferon alfa-2b and ribavirin on liver fibrosis in patients with chronic hepatitis C. Gastroenterology 2002;122:1303-13.

49. Morgan RL, Baack B, Smith BD, Yartel A, Pitasi M, et al. Eradication of hepatitis C virus infection and the development of hepatocellular carcinoma: a meta-analysis of observational studies. Ann Intern Med 2013;158:329-37.

50. van der Meer AJ, Veldt BJ, Feld JJ, Wedemeyer H, Dufour JF, et al. Association between sustained virological response and all-cause mortality among patients with chronic hepatitis C and advanced hepatic fibrosis. JAMA 2012;308:2584-93.

51. Veldt BJ, Heathcote EJ, Wedemeyer H, Reichen J, Hofmann WP, et al. Sustained virologic response and clinical outcomes in patients with chronic hepatitis C and advanced fibrosis. Ann Intern Med 2007;147:677-84.

52. Johnson RJ, Gretch DR, Couser WG, Alpers CE, Wilson J, et al. Hepatitis C virus-associated glomerulonephritis. Effect of alphainterferon therapy. Kidney Int 1994;46:1700-4.

53. Arase Y, Suzuki F, Suzuki Y, Akuta N, Kobayashi M, et al. Sustained virological response reduces incidence of onset of type 2 diabetes in chronic hepatitis C. Hepatology 2009;49:739-44.

54. Takikawa H, Yamazaki R, Shoji S, Miyake K, Yamanaka M. Normalization of urinary porphyrin level and disappearance of skin lesions after successful interferon therapy in a case of chronic hepatitis C complicated with porphyria cutanea tarda. J Hepatol 1995;22:249-50.

55. Ghany MG, Strader DB, Thomas DL, Seeff LB; American Association for the Study of Liver Diseases. Diagnosis, management, and treatment of hepatitis C: an update. Hepatology 2009;49:1335-74.

56. Jézéquel C, Bardou-Jacquet E, Desille Y, Renard I, Lainé F, et al. Survival of patients infected by chronic hepatitis C and F0F1 fibrosis at baseline after a 15 year follow-up. J Hepatol 2015;62:S589.

57. Øvrehus ALH, Blach S, Christensen PB, Gerstoft J, Weis N, et al. Impact of prioritizing treatment in a high resource setting minimizing the burden of HCV related disease in 15 years. J Hepatol 2015;62:S591-2.

58. CROI. Impact of deferring HCV treatment on liver-related events in HIV+ patients. Available from: http://www.croiconference.org/ sessions/impact-deferring-hcv-treatment-liver-related-events-hiv-patients. [Last accessed on 28 Nov 2018]

59. Gerber L, Estep M, Stepanova M, Escheik C, Weinstein A, et al. Effects of viral eradication with ledipasvir and sofosbuvir, with or without ribavirin, on measures of fatigue in patients with chronic hepatitis C virus infection. Clin Gastroenterol Hepatol.2016;14:15 -64.

60. Younossi ZM, Jiang Y, Smith NJ, Stepanova M, Beckerman R. Ledipasvir/sofosbuvir regimens for chronic hepatitis C infection: insights from a work productivity economic model from the United States. Hepatology 2015;61:1471-8.

61. Younossi ZM, Stepanova M, Sulkowski M, Naggie S, Puoti M, et al. Sofosbuvir and ribavirin for treatment of chronic hepatitis C in patients coinfected with hepatitis C virus and HIV: the impact on patient-reported outcomes. J Infect Dis 2015;212:367-77.

62. Bonkovsky HL, Snow KK, Malet PF, Back-Madruga C, Fontana RJ, et al. Health-related quality of life in patients with chronic hepatitis C and advanced fibrosis. J Hepatol 2007;46:420-31.

63. Reig M, Mariño Z, Perelló C, Iñarrairaegui M, Ribeiro A, et al. Unexpected high rate of early tumor recurrence in patients with $\mathrm{HCV}$ related HCC undergoing interferon-free therapy. J Hepatol 2016;65:719-26.

64. ANRS collaborative study group on hepatocellular carcinoma (ANRS CO22 HEPATHER, CO12 CirVir and CO23 CUPILT cohorts). Lack of evidence of an effect of direct acting antivirals on the recurrence of hepatocellular carcinoma: The ANRS collaborative study group on hepatocellular carcinoma: data from three ANRS cohorts. J Hepatol 2016;65:734-40.

65. Waziry R, Hajarizadeh B, Grebely J, Amin J, Law M, et al. Hepatocellular carcinoma risk following direct-acting antiviral HCV therapy: a systematic review, meta-analyses, and meta-regression. J Hepatol 2017;67:1204-12.

66. Backus LI, Belperio PS, Shahoumian TA, Mole LA. Impact of sustained virologic response with direct-acting antiviral treatment on mortality in patients with advanced liver disease. Hepatology 2017; doi: 10.1002/hep.29408.

67. Grebely J, Oser M, Taylor LE, Dore GJ. Breaking down the barriers to hepatitis C virus (HCV) treatment among individuals with HCV/HIV coinfection: action required at the system, provider, and patient levels. J Infect Dis 2013;207:S19-25.

68. Harris M, Rhodes T. Hepatitis C treatment access and uptake for people who inject drugs: a review mapping the role of social factors. Harm Reduct J 2013;10:7.

69. Wolfe D, Luhmann N, Harris M, Momenghalibaf A, Albers E, et al. Human rights and access to hepatitis C treatment for people who inject drugs. Int J Drug Policy 2015;26:1072-80.

70. Aspinall EJ, Corson S, Doyle JS, Grebely J, Hutchinson SJ, et al. Treatment of hepatitis C virus infection among people who are actively injecting drugs: a systematic review and meta-analysis. Clin Infect Dis 2013;57:S80-9.

71. Dore GJ, Altice F, Litwin AH, Dalgard O, Gane EJ, et al. Elbasvir-grazoprevir to treat hepatitis C virus infection in persons receiving opioid agonist therapy: a randomized trial. Ann Intern Med 2016;165:625-34.

72. Feld JJ, Kowdley KV, Coakley E, Sigal S, Nelson DR, et al. Treatment of HCV with ABT-450/r-ombitasvir and dasabuvir with 
ribavirin. N Engl J Med 2014;370:1594-603.

73. Grebely J, Dore GJ, Zeuzem S, Aspinall RJ, Fox R, et al. Efficacy and safety of sofosbuvir/velpatasvir in patients with chronic hepatitis c virus infection receiving opioid substitution therapy: analysis of phase 3 ASTRAL trials. Clin Infect Dis 2016;63:1479-81.

74. Grebely J, Puoti M, Wedemeyer H, Cooper CS, Sulkowski MS, et al. Safety and efficacy of ombitasvir, paritaprevir/ritonavir and dasabuvir with or without ribavirin in chronic hepatitis $\mathrm{C}$ patients receiving opioid substitution therapy: a pooled analysis across 12 clinical trials. J Hepatol 2017;66:S514

75. Grebely J, Mauss S, Brown A, Bronowicki JP, Puoti M, et al. Efficacy and safety of ledipasvir/sofosbuvir with and without ribavirin in patients with chronic HCV genotype 1 infection receiving opioid substitution therapy: analysis of phase 3 ION trials. Clin Infect Dis 2016;63:1405-11

76. Read P, Lothian R, Chronister K, Gilliver R, Kearley J, et al. Delivering direct acting antiviral therapy for hepatitis C to highly marginalised and current drug injecting populations in a targeted primary health care setting. Int J Drug Policy 2017;47:209-15.

77. Mason K, Dodd Z, Guyton M, Tookey P, Lettner B, et al. Understanding real-world adherence in the directly acting antiviral era: a prospective evaluation of adherence among people with a history of drug use at a community-based program in Toronto, Canada. Int J Drug Policy 2017;47:202-8.

78. Mazhnaya A, Meteliuk A, Barnard T, Zelenev A, Filippovych S, et al. Implementing and scaling up HCV treatment services for people who inject drugs and other high risk groups in Ukraine: an evaluation of programmatic and treatment outcomes. Int J Drug Policy 2017;47:187-95

79. Norton BL, Fleming J, Bachhuber MA, Steinman M, DeLuca J, et al. High HCV cure rates for people who use drugs treated with direct acting antiviral therapy at an urban primary care clinic. Int J Drug Policy 2017;47:196-201.

80. Boglione L, Mornese Pinna S, De Nicolò A, Cusato J, Cariti G, et al. Treatment with direct-acting antiviral agents of hepatitis C virus infection in injecting drug users: a prospective study. J Viral Hepat 2017;24:850-7.

81. Grebely J, Dalgard O, Conway B, Cunningham E, Bruggmann P, et al. Efficacy and safety of sofosbuvir/velpatasvir in people with chronic hepatitis C virus infection and recent injecting drug use: The SIMPLIFY study. J Hepatol 2017;66:S513.

82. Martin NK, Vickerman P, Foster GR, Hutchinson SJ, Goldberg DJ, et al. Can antiviral therapy for hepatitis C reduce the prevalence of HCV among injecting drug user populations? A modeling analysis of its prevention utility. J Hepatol 2011;54:1137-44.

83. Martin NK, Hickman M, Hutchinson SJ, Goldberg DJ, Vickerman P. Combination interventions to prevent HCV transmission among people who inject drugs: modeling the impact of antiviral treatment, needle and syringe programs, and opiate substitution therapy Clin Infect Dis 2013;57:S39-45.

84. WHO. Guidelines for the screening, care and treatment of persons with chronic hepatitis C infection. Available from: http://apps.who. int/iris/bitstream/10665/205035/1/9789241549615_eng.pdf. [Last accessed on 28 Nov 2018]

85. AASLD/IDSA. HCV guidance: recommendations for testing, managing and treating hepatitis C. Available from: http://www. hcvguidelines.org. [Last accessed on 28 Nov 2018]

86. EASL. Recommendations on treatment of hepatitis C. Available from: http://www.easl.eu/medias/cpg/HCV2016/English-report.pdf. [Last accessed on 28 Nov 2018]

87. Grebely J, Robaeys G, Bruggmann P, Aghemo A, Backmund M, et al. Recommendations for the management of hepatitis C virus infection among people who inject drugs. Intl J Drug Policy 2015;26:1028-38.

88. EASL. Sustained virological response to oral hepatitis $\mathrm{C}$ virus treatment associated with reduced mortality in an Italian cohort. Available from: https://medicalxpress.com/news/2018-04-sustained-virological-response-oral-hepatitis.html. [Last accessed on 28 Nov 2018]

89. Infohep. Direct-acting antivirals bring fewer HCV-related liver transplants, better survival after transplantation, in Europe. Available from: www.infohep.org/Direct-acting-antivirals-bring-fewer-HCV-related-liver-transplants-better-survival-after-transplantation-inEurope/page/3257600/. [Last accessed on 28 Nov 2018]

90. Stanaway JD, Flaxman AD, Naghavi M, Fitzmaurice C, Vos T, et al.The global burden of viral hepatitis from 1990 to 2013: findings from the global burden of disease study 2013. Lancet 2016;388:1081-8.

91. Konerman MA, Lok ASF. Hepatitis c treatment and barriers to eradication. Clin Transl Gastroenterol 2016;7:e193.

92. Mugavero MJ, Amico KR, Horn T, Thompson MA. The state of engagement in HIV care in the United States: from cascade to continuum to control. Clin Infect Dis 2013;57:1164-71.

93. Holmberg SD, Spradling PR, Moorman AC, Denniston MM. Hepatitis C in the United States. N Engl J Med 2013;368:1859-61.

94. Stein JA, Andersen RM, Robertson M, Gelberg L. Impact of hepatitis B and C infection on health services utilization in homeless adults: a test of the Gelberg-Andersen behavioral model for vulnerable populations. Health Psychol 2012;31:20-30.

95. Desai RA, Rosenheck RA, Agnello V. Prevalence of hepatitis C virus infection in a sample of homeless veterans. Soc Psychiatry Psychiatr Epidemiol 2003;38:396-401.

96. Nyamathi AM, Dixon EL, Robbins W, Smith C, Wiley D, et al. Risk factors for hepatitis C virus infection among homeless adults. J Gen Intern Med 2002;17:134-43.

97. Stein JA, Nyamathi A. Correlates of hepatitis C virus infection in homeless men: a latent variable approach. Drug Alcohol Depend 2004;75:89-95.

98. Marinho RT, Barreira DP. Hepatitis C, stigma and cure. World J Gastroenterol 2013;19:6703-9.

99. Grundy G, Beeching N. Understanding social stigma in women with hepatitis C. Nurs Stand 2004;19:35-9.

100. Paterson BL, Backmund M, Hirsch G, Yim C. The depiction of stigmatization in research about hepatitis C. Int J Drug Policy 2007; 18:364-73

101. Schäfer M, Boetsch T, Laakmann G. Psychosis in a methadone-substituted patient during interferon-alpha treatment of hepatitis C. Addiction 2000;95:1101-4.

102. Bogart LM, Cowgill BO, Kennedy D, Ryan G, Murphy DA, et al. HIV-related stigma among people with HIV and their families: a 
qualitative analysis. AIDS Behav 2008;12:244-54.

103. Butt G. Stigma in the context of hepatitis C: concept analysis. J Adv Nurs 2008;62:712-24.

104. Zickmund S, Ho EY, Masuda M, Ippolito L, LaBrecque DR. "They treated me like a leper". Stigmatization and the quality of life of patients with hepatitis C. J Gen Intern Med 2003;18:835-44.

105. Dowsett LE, Coward S, Lorenzetti DL, MacKean G, Clement F. Living with hepatitis C virus: a systematic review and narrative synthesis of qualitative literature. Can J Gastroenterol Hepatol 2017;2017:3268650.

106. Nelson PK, Mathers BM, Cowie B, Hagan H, Des Jarlais D, et al. Global epidemiology of hepatitis B and hepatitis C in people who inject drugs: results of systematic reviews. Lancet 2011;378:571-83.

107. Hajarizadeh B, Grebely J, Dore GJ. Epidemiology and natural history of HCV infection. Nat Rev Gastroenterol Hepatol 2013;10:553-62.

108. Hagan H, Pouget ER, Des Jarlais DC, Lelutiu-Weinberger C. Meta-regression of hepatitis C virus infection in relation to time since onset of illicit drug injection: the influence of time and place. Am J Epidemiol 2008;168:1099-109.

109. Morris MD, Shiboski S, Bruneau J, Hahn JA, Hellard M, et al. Geographic differences in temporal incidence trends of hepatitis C virus infection among people who inject drugs: the InC3 collaboration. Clin Infect Dis 2017;64:860-9.

110. Page K, Morris MD, Hahn JA, Maher L, Prins M. Injection drug use and hepatitis C virus infection in young adult injectors: using evidence to inform comprehensive prevention. Clin Infect Dis 2013;57:S32-8.

111. Wiessing L, Ferri M, Grady B, Kantzanou M, Sperle I, et al. Hepatitis C virus infection epidemiology among people who inject drugs in Europe: a systematic review of data for scaling up treatment and prevention. PLoS One 2014;9:e103345.

112. Committee on a National Strategy for the Elimination of Hepatitis B and C; Board on Population Health and Public Health Practice; Health and Medicine Division; National Academies of Sciences, Engineering, and Medicine. Eliminating the public health problem of hepatitis B and C in the United States: phase one report. Available from: https://www.ncbi.nlm.nih.gov/pubmed/?term=Eliminating+th e+ public + health + problem + of + hepatitis $+\mathrm{B}+$ and $+\mathrm{C}+\mathrm{in}+$ the+United + States\%3A+phase + one + report. [Last accessed on 28 Nov 2018]

113. Zibbell JE, Iqbal K, Patel RC, Suryaprasad A, Sanders KJ, et al. Increases in hepatitis C virus infection related to injection drug use among persons aged $\leq 30$ years - Kentucky, Tennessee, Virginia, and West Virginia, 2006-2012. MMWR Morb Mortal Wkly Rep 2015;64:453-8.

114. Suryaprasad AG, White JZ, Xu F, Eichler BA, Hamilton J, et al. Emerging epidemic of hepatitis C virus infections among young nonurban persons who inject drugs in the United States, 2006-2012. Clin Infect Dis 2014;59:1411-9.

115. Van Handel MM, Rose CE, Hallisey EJ, Kolling JL, Zibbell JE, et al. County-level vulnerability assessment for rapid dissemination of HIV or HCV infections among persons who inject drugs, United States. J Acquir Immune Defic Syndr 2016;73:323-31.

116. Harris AM, Iqbal K, Schillie S, Britton J, Kainer MA, et al. Increases in acute hepatitis B virus infections - Kentucky, Tennessee, and West Virginia, 2006-2013. MMWR Morb Mortal Wkly Rep 2016;65:47-50.

117. Iversen J, Grebely J, Catlett B, Cunningham P, Dore GJ, et al. Estimating the cascade of hepatitis C testing, care and treatment among people who inject drugs in Australia. Int J Drug Policy 2017;47:77-85.

118. Butler K, Day C, Sutherland R, van Buskirk J, Breen C, et al. Hepatitis C testing in general practice settings: a cross-sectional study of people who inject drugs in Australia. Int J Drug Policy 2017;47:102-6.

119. van Santen DK, van der Helm JJ, Lindenburg K, Schim van der Loeff M, Prins M. HIV and hepatitis C treatment uptake among people who use drugs participating in the Amsterdam cohort studies, 1985-2015. Int J Drug Policy 2017;47:95-101.

120. Chan DP, Sun HY, Wong HT, Lee SS, Hung CC. Sexually acquired hepatitis C virus infection: a review. Int J Infect Dis 2016;49:47-58.

121. Ingiliz P, Martin TC, Rodger A, Stellbrink HJ, Mauss S et al. HCV reinfection incidence and spontaneous clearance rates in HIVpositive men who have sex with men in Western Europe. J Hepatol 2017;66:282-7.

122. Salazar-Vizcaya L, Kouyos RD, Zahnd C, Wandeler G, Battegay M, et al. Hepatitis C virus transmission among human immunodeficiency virus-infected men who have sex with men: modeling the effect of behavioral and treatment interventions. Hepatology 2016;64:1856-69.

123. Dore GJ. Hepatitis C treatment as prevention among HIV infected men who have sex with men: feasible? Hepatology 2016;64:1834-6.

124. Martin TC, Singh GJ, McClure M, Nelson M. HCV reinfection among HIV-positive men who have sex with men: a pragmatic approach. Hepatology 2015;61:1437.

125. Hagan H, Jordan AE, Neurer J, Cleland CM. Incidence of sexually transmitted hepatitis C virus infection in HIV-positive men who have sex with men. AIDS 2015;29:2335-45.

126. Abravanel F, Métivier S, Chauveau M, Péron JM, Izopet J. Transmission of HCV NS5A inhibitor-resistant variants among HIVinfected men who have sex with men. Clin Infect Dis 2016;63:1271-2.

127. Pineda JA, Núñez-Torres R, Téllez F, Mancebo M, García F, et al. Hepatitis C virus reinfection after sustained virological response in HIV-infected patients with chronic hepatitis C. J Infect 2015;71:571-7.

128. Young J, Rossi C, Gill J, Walmsley S, Cooper C, et al. Risk factors for hepatitis C virus reinfection after sustained virologic response in patients coinfected with HIV. Clin Infect Dis 2017;64:1154-62.

129. Dore GJ, Altice F, Litwin AH, Dalgard O, Gane EJ, et al. Elbasvir-grazoprevir to treat hepatitis C virus infection in persons receiving opioid agonist therapy: a randomized trial. Ann Intern Med 2016;165:625-34.

130. Midgard H, Bjøro B, Mæland A, Konopski Z, Kileng H, et al. Hepatitis C reinfection after sustained virological response. J Hepatol 2016;64:1020-6.

131. Thomas DL, Astemborski J, Rai RM, Anania FA, Schaeffer M, et al. The natural history of hepatitis C virus infection: host, viral, and environmental factors. JAMA 2000;284:450-6.

132. Mehta SH, Cox A, Hoover DR, Wang XH, Mao Q, et al. Protection against persistence of hepatitis C. Lancet 2002;359:1478-83.

133. Larney S, Kopinski H, Beckwith CG, Zaller ND, Jarlais DD, et al. Incidence and prevalence of hepatitis C in prisons and other closed settings: results of a systematic review and meta-analysis. Hepatology 2013;58:1215-24.

134. UNSW. National prison entrants' bloodborne virus and risk behaviour survey report 2004, 2007, 2010, and 2013 . Available from: 
https://kirby.unsw.edu.au/report/national-prison-entrants-bloodborne-virus-and-risk-behaviour-survey-report-2004-2007-2010-and. [Last accessed on 28 Nov 2018]

135. Zampino R, Coppola N, Sagnelli C, Di Caprio G, Sagnelli E. Hepatitis C virus infection and prisoners: epidemiology, outcome and treatment. World J Hepatol 2015;7:2323-30.

136. Walmsley R. World prison population list. 11th ed. Birckbeck University of London: Institute for Criminal Policy Research; 2016.

137. United Nations. 45/111. Basic principles for the treatment of prisoners. Available from: http://www.un.org/documents/ga/res/45/ a45r111.htm. [Last accessed on 28 Nov 2018]

138. Bretschneider W, Elger BS. Expert perspectives on Western European prison health services: do ageing prisoners receive equivalent care? J Bioeth Inq 2014;11:319-32.

139. de Viggiani N. Unhealthy prisons: exploring structural determinants of prison health. Sociol Health Illn 2007;29:115-35.

140. Teutsch S, Luciani F, Scheuer N, McCredie L, Hosseiny P, et al. Incidence of primary hepatitis C infection and risk factors for transmission in an Australian prisoner cohort. BMC Public Health 2010;10:633.

141. Dolan K, Teutsch S, Scheuer N, Levy M, Rawlinson W, et al. Incidence and risk for acute hepatitis C infection during imprisonment in Australia. Eur J Epidemiol 2010;25:143-8.

142. Skipper C, Guy JM, Parkes J, Roderick P, Rosenberg WM, et al. Evaluation of a prison outreach clinic for the diagnosis and prevention of hepatitis C: implications for the national strategy. Gut 2003;52:1500-4.

143. Spaulding AC, Weinbaum CM, Lau DT, Sterling R, Seeff LB, et al. A framework for management of hepatitis C in prisons. Ann Intern Med 2006;144:762-9.

144. Yap L, Carruthers S, Thompson S, Cheng W, Jones J, et al. A descriptive model of patient readiness, motivators, and hepatitis C treatment uptake among Australian prisoners. PLoS One 2014;9:e87564.

145. Lloyd AR, Clegg J, Lange J, Stevenson A, Post JJ, et al. Safety and effectiveness of a nurse-led outreach program for assessment and treatment of chronic hepatitis $C$ in the custodial setting. Clin Infect Dis 2013;56:1078-84.

146. Fazel S, Baillargeon J. The health of prisoners. Lancet 2011;377:956-65.

147. Spaulding AC, Perez SD, Seals RM, Hallman MA, Kavasery R, et al. Diversity of release patterns for jail detainees: implications for public health interventions. Am J Public Health 2011;101:S347-52.

148. McGowan CE, Fried MW. Barriers to hepatitis C treatment. Liver Int 2012;32:151-6.

149. Zickmund SL, Brown KE, Bielefeldt K. A systematic review of provider knowledge of hepatitis C: is it enough for a complex disease? Dig Dis Sci 2007;52:2550-6.

150. Shehab TM, Sonnad SS, Lok AS. Management of hepatitis C patients by primary care physicians in the USA: results of a national survey. J Viral Hepat 2001;8:377-83.

151. Kanwal F, Hoang T, Spiegel BM, Eisen S, Dominitz JA, et al. Predictors of treatment in patients with chronic hepatitis C infection role of patient versus nonpatient factors. Hepatology 2007;46:1741-9.

152. Stoové MA, Gifford SM, Dore GJ. The impact of injecting drug use status on hepatitis C-related referral and treatment. Drug Alcohol Depend 2005;77:81-6

153. Volk ML. Antiviral therapy for hepatitis C: why are so few patients being treated? J Antimicrob Chemother 2010;65:1327-9.

154. Iyengar S, Tay-Teo K, Vogler S, Beyer P, Wiktor S, et al. Prices, costs, and affordability of new medicines for hepatitis C in 30 countries: an economic analysis. PLoS Med 2016;13:e1002032.

155. Saag MS. Editorial commentary: getting smart in how we pay for HCV drugs: KAOS vs CONTROL. Clin Infect Dis 2015;61:169-70.

156. US Senate Committee on Finance. The Price of Sovaldi and its impact on the U.S. Health Care System. Available from: https://www. finance.senate.gov/imo/media/doc/2\%20Introduction, $\% 20$ Hepatitis $\% 20 \mathrm{C} \% 20 \mathrm{Background}, \% 20 \mathrm{Development} \% 20$ of $\% 20$ Sovaldi $\% 20$ and\%20Gilead's\%20Acquistion\%20of\%20Pharmasset\%20(Introduction,\%20Sections\%201\&2).pdf. [Last accessed on 28 Nov 2018]

157. WHO. Global report on access to hepatitis C treatment. Focus on overcoming barriers. Available from: http://apps.who.int/iris/ handle/10665/250625. [Last accessed on 28 Nov 2018]

158. Morgan JR, Servidone M, Easterbrook P, Linas BP. Economic evaluation of HCV testing approaches in low and middle income countries. BMC Infect Dis 2017;17:697.

159. WHO. Guidelines on hepatitis B and C testing. Available from: http://www.who.int/hepatitis/publications/guidelines-hepatitis-c-btesting/en/. [Last accessed on 28 Nov 2018]

160. Stein K, Dalziel K, Walker A, Jenkins B, Round A, et al. Screening for hepatitis C in genito-urinary medicine clinics: a cost utility analysis. J Hepatol 2003;39:814-25.

161. Coffin PO, Scott JD, Golden MR, Sullivan SD. Cost-effectiveness and population outcomes of general population screening for hepatitis C. Clin Infect Dis 2012;54:1259-71.

162. Wong WW, Tu HA, Feld JJ, Wong T, Krahn M. Cost-effectiveness of screening for hepatitis C in Canada. CMAJ 2015;187:E110-21.

163. Goel A, Chen Q, Chhatwal J, Aggarwal R. Cost-effectiveness of generic pan-genotypic sofosbuvir/velpatasvir versus genotypedependent direct-acting antivirals for hepatitis C treatment. J Gastroenterol Hepatol 2018; doi: 10.1111/jgh.14301.

164. Peeling RW, Boeras DI, Marinucci F, Easterbrook P. The future of viral hepatitis testing: innovations in testing technologies and approaches. BMC Infect Dis 2017;17:699.

165. Dore GJ, Ward J, Thursz M. Hepatitis C disease burden and strategies to manage the burden (Guest Editors Mark Thursz, Gregory Dore and John Ward). J Viral Hepat 2014;21:1-4.

166. Bruggmann P, Berg T, Øvrehus AL, Moreno C, Brandão Mello CE, et al. Historical epidemiology of hepatitis C virus (HCV) in selected countries. J Viral Hepat 2014;21:5-33.

167. Chen DS, Hamoudi W, Mustapha B, Layden J, Nersesov A, et al. Strategies to manage hepatitis C virus infection disease burdenVolume 4. J Viral Hepat 2017;24:44-63.

168. Denniston MM, Jiles RB, Drobeniuc J, Klevens RM, Ward JW, et al. Chronic hepatitis C virus infection in the United States, National 
health and nutrition examination survey 2003 to 2010. Ann Intern Med 2014;160:293-300.

169. Razavi H, Waked I, Sarrazin C, Myers RP, Idilman R, et al. The present and future disease burden of hepatitis c virus (HCV) infection with today's treatment paradigm. J Viral Hepat 2014;21:34-59.

170. Hepatitis B and C Public Policy Association ASBL. Hepatitis C elimination in Europe - European policy guidelines. Available from: http://www.hcvbrusselssummit.eu/images/documents/reports/HCV-Elimination-PolicyGuidelines.pdf. [Last accessed on 28 Nov 2018]

171. Arora S, Thornton K, Murata G, Deming P, Kalishman S, et al. Outcomes of treatment for hepatitis C virus infection by primary care providers. N Engl J Med 2011;364:2199-207.

172. Hill WD, Butt G, Alvarez M, Krajden M. Capacity enhancement of hepatitis C virus treatment through integrated, community-based care. Can J Gastroenterol 2008;22:27-32.

173. Lloyd AR, Clegg J, Lange J, Stevenson A, Post JJ, et al. Safety and effectiveness of a nurse-led outreach program for assessment and treatment of chronic hepatitis C in the custodial setting. Clin Infect Dis 2013;56:1078-84.

174. Hill WD, Butt G, Alvarez M, Krajden M. Capacity enhancement of hepatitis C virus treatment through integrated, community-based care. Can J Gastroenterol 2008;22:27-32.

175. Nazareth S, Kontorinis N, Muwanwella N, Hamilton A, Leembruggen N, et al. Successful treatment of patients with hepatitis C in rural and remote Western Australia via telehealth. J Telemed Telecare 2013;19:101-6.

176. Beste LA, Glorioso TJ, Ho PM, Au DH, Kirsh SR, et al. Telemedicine specialty support promotes hepatitis C treatment by primary care providers in the department of veterans affairs. Am J Med 2017;130:432-8.

177. Kattakuzhy S, Gross C, Emmanuel B, Teferi G, Jenkins V, et al. Expansion of treatment for hepatitis C virus infection by task shifting to community-based nonspecialist providers: a nonrandomized clinical trial. Ann Intern Med 2017;167:311-8.

178. Mera J, Vellozzi C, Hariri S, Carabin H, Drevets DA, et al. Identification and clinical management of persons with chronic hepatitis C virus infection - Cherokee Nation, 2012-2015. MMWR Morb Mortal Wkly Rep 2016;65:461-6.

179. Hellard M, Sacks-Davis R, Doyle J. Hepatitis C elimination by 2030 through treatment and prevention: think global, act in local networks. J Epidemiol Community Health 2016;70:1151-4.

180. Centers for Disease Control and Prevention (CDC). Integrated prevention services for HIV infection, viral hepatitis, sexually transmitted diseases, and tuberculosis for persons who use drugs illicitly: summary guidance from CDC and the U.S. Department of Health and Human Services. Available from: https://www.cdc.gov/mmwr/preview/mmwrhtml/rr6105a1.htm. [Last accessed on $28 \mathrm{Nov}$ 2018]

181. Scott N, Ólafsson S, Gottfreðsson M, Tyrfingsson T, Rúnarsdóttir V, et al. Modelling the elimination of hepatitis C as a public health threat in Iceland: a goal attainable by 2020. J Hepatol 2018;68:932-9.

182. European Union HCV Collaborators. Hepatitis C virus prevalence and level of intervention required to achieve the WHO targets for elimination in the European Union by 2030: a modelling study. Lancet Gastroenterol Hepatol 2017;2:325-36.

183. Dore GJ, Hajarizadeh B. Elimination of hepatitis C virus in Australia: laying the foundation. Infect Dis Clin North Am 2018;32:269-79.

184. National Academies of Sciences, Engineering, and Medicine; Health and Medicine Division; Board on Population Health and Public Health Practice; Committee on a National Strategy for the Elimination of Hepatitis B and C. Modeling the Elimination of Hepatitis C in the United States. In: Strom BL, Buckley GJ, editors. A National Strategy for the Elimination of Hepatitis B and C: Phase Two Report. Washington (DC): National Academies Press (US); 2017.

185. Suryaprasad AG, White JZ, Xu F, Eichler BA, Hamilton J, et al. Emerging epidemic of hepatitis C virus infections among young nonurban persons who inject drugs in the United States, 2006-2012. Clin Infect Dis 2014;59:1411-9.

186. Holmberg SD, Spradling PR, Moorman AC, Denniston MM. Hepatitis C in the United States. N Engl J Med 2013;368:1859-61.

187. Belperio PS, Chartier M, Gonzalez RI, Park AM, Ross DB, et al. Hepatitis C care in the department of veterans affairs: building a foundation for success. Infect Dis Clin North Am 2018;32:281-92.

188. HHS.gov. The community response to viral hepatitis - contributions towards achieving the goals of the viral hepatitis action plan. Available from: https://www.hhs.gov/hepatitis/action-plan/viral-hepatitis-community-action/community-response-to-viral-hepatitis/ index.html. [Last accessed on 29 Nov 2018]

189. Waked I, Doss W, El-Sayed MH, Estes C, Razavi H, et al. The current and future disease burden of chronic Hepatitis C virus infection in Egypt. Arab J Gastroenterol 2014;15:45-52.

190. The World Bank. Treatment program policy analysis 2017 (English). Available from: http://documents.worldbank.org/curated/ en/335981517329520478/Treatment-program-policy-analysis-2017. [Last accessed on 28 Nov 2018]

191. The World Bank. Eliminating hepatitis C from Egypt: 2017 update on current trends and policyrecommendations - policy brief (English). Available from: http://documents.worldbank.org/curated/en/164381517333701631/Eliminating-Hepatitis-C-from-Egypt2017-update-on-current-trends-and-policyrecommendations-policy-brief. [Last accessed on 28 Nov 2018]

192. Mitruka K, Tsertsvadze T, Butsashvili M, Gamkrelidze A, Sabelashvili P, et al. Launch of a nationwide hepatitis C elimination program - Georgia, April 2015. MMWR Morb Mortal Wkly Rep 2015;64:753-7.

193. Gvinjilia L, Nasrullah M, Sergeenko D, Tsertsvadze T, Kamkamidze G, et al. National progress toward hepatitis C elimination Georgia, 2015-2016. MMWR Morb Mortal Wkly Rep 2016;65:1132-5.

194. Nasrullah M, Sergeenko D, Gvinjilia L, Gamkrelidze A, Tsertsvadze T, et al. The role of screening and treatment in national progress toward hepatitis C elimination - Georgia, 2015-2016. MMWR Morb Mortal Wkly Rep 2017;66:773-6.

195. WHO. Brazil sets out path to eliminate hepatitis C by 2030. Available from: http://www.worldhepatitissummit.org/docs/defaultsource/press-releases/government-of-brazil/brazil-sets-out-path-to-eliminate-hepatitis-c-by-2030.pdf?sfvrsn=2. [Last accessed on 28 Nov 2018]

196. Leidner AJ, Chesson HW, Xu F, Ward JW, Spradling PR, et al. Cost-effectiveness of hepatitis C treatment for patients in early stages of liver disease. Hepatology 2015;61:1860-9.

197. Harris RJ, Martin NK, Rand E, Mandal S, Mutimer D, et al. New treatments for hepatitis C virus (HCV): scope for preventing liver disease and HCV transmission in England. J Viral Hepat 2016;23:631-43. 
198. Martin NK, Vickerman P, Dore GJ, Grebely J, Miners A, et al. Prioritization of HCV treatment in the direct-acting antiviral era: an economic evaluation. J Hepatol 2016;65:17-25.

199. Hickman M, Martin NK, Huxtable R. Hepatitis C virus prevention and treatment prioritization - ethical, economic and evidential dimensions of early rather than delayed treatment for people who inject drugs. Addiction 2017;112:201-3.

200. Lazarus JV, Stumo SR, Harris M, Hendrickx G, Hetherington KL, et al. Hep-CORE: a cross-sectional study of the viral hepatitis policy environment reported by patient groups in 25 European countries in 2016 and 2017. J Int AIDS Soc 2018;21:e25052.

201. Box GEP. Science and statistics. J Am Stat Assoc 1976;71:791-9.

202. Wiktor SZ. Where next for hepatitis B and C surveillance? J Viral Hepat 2015;22:571-3.

203. Sixty-seventh World Health Assembly. Hepatitis. Available from: http://apps.who.int/gb/ebwha/pdf files/WHA67/A67 R6-en.pdf. [Last accessed on 28 Nov 2018]

204. Lazarus JV, Mozalevskis A, Safreed-Harmon K, Eramova I. Strengthening hepatitis B and C surveillance in Europe: results from the two global hepatitis policy surveys (2013 and 2014). Hepatol Med Policy 2016;1:3.

205. WHO. WHO-recommended standards for surveillance of selected vaccine-preventable diseases. Available from: www. measlesrubellainitiative.org/wp-content/uploads/2013/06/WHO-surveillance-standard.pdf. [Last accessed on 28 Nov 2018]

206. Irving WL, Brown RJ. Acute hepatitis C virus infection: a dynamic-and challenging-concept. J Infect Dis 2010;202:1765-7.

207. Klevens RM, Miller J, Vonderwahl C, Speers S, Alelis K, et al. Population-based surveillance for hepatitis C virus, United States, 2006-2007. Emerg Infect Dis 2009;15:1499-502.

208. The National Academies Press. Hepatitis and liver cancer: a national strategy for prevention and control of hepatitis B and C (2010). Available from: http://www.nap.edu/catalog/12793.html. [Last accessed on 28 Nov 2018] 